\title{
COMPARISON OF CLINICO-PATHOLOGICAL FEATURES AND PROGNOSIS OF TRIPLE-NEGATIVE AND NON-TRIPLE-NEGATIVE FEMALE BREAST CANCER PATIENTS
}

\author{
Nonam Chellappan1, Smitha G. Raj²
}

${ }_{1}^{1}$ Assistant Professor, Department of Radiotherapy, Government T. D. Medical College, Alappuzha, Kerala, India.

${ }^{2}$ Assistant Professor, Department of Anatomy, Government T. D. Medical College, Alappuzha, Kerala, India.

\begin{tabular}{l}
\hline ABSTRACT \\
BACKGROUND \\
Triple-negative breast cancer patients have no expression of Oestrogen Receptor (ER), Progesterone Receptor (PR) and there is \\
neither expression nor amplification of human epidermal growth factor receptor 2 in a tumour. But non-triple negative breast \\
cancer patients have either oestrogen receptor or progesterone receptor or both positive with or without amplification of Hum an \\
epidermal growth factor receptor 2 in a tumour. \\
The purpose of this retrospective study is to compare and analyse the clinico-pathological features, recurrence, metastasis and \\
prognosis of triple-negative breast cancer patients and non-triple negative breast cancer patients.
\end{tabular}

\section{MATERIALS AND METHODS}

A retrospective descriptive study for a total of 200 stage III female breast cancer patients (100 triple-negative patients and 100 non-triple-negative patients) were diagnosed and treated at the Department of Radiotherapy, T.D Medical College Hospital, Alappuzha from January $1^{\text {st }} 2011$ to December 31st 2011. The clinical features, recurrence, metastasis and prognosis of the two groups were compared.

\section{RESULTS}

The triple-negative breast cancer patients were characterised as younger age, higher histological grade, bigger tumour size, higher clinical stage at diagnosis, more recurrence and metastasis, lower 5-year disease free survival rate and 5-year overall survival rate. The lungs, liver and brain were the first three most common sites of metastases.

\section{CONCLUSION}

In our study, we found that triple-negative breast cancer was a distinct subgroup of breast cancer with particular clinico-pathologic behaviour. Compared with the non-triple-negative breast cancer, triple-negative breast cancer was characterised by more aggressive behaviour, metastasis tendency and lower disease-free survival and overall survival rate. This result suggested that characteristics like family history, premenopausal status, tumour size, histological grade of triple-negative breast cancer patients had more local relapse and metastases than that of in non-triple-negative breast cancer that was statistically significant.

\section{KEY WORDS}

Clinico-Pathologic Behaviour, Triple-Negative Breast Cancer, Recurrence, Metastasis.

HOW TO CITE THIS ARTICLE: Chellappan N, Raj SG. Comparison of clinico-pathological features and prognosis of triple-negative and non-triple-negative female breast cancer patients. J. Evolution Med. Dent. Sci. 2018;7(30):3412-3418, DOI: $10.14260 /$ jemds/2018/770

\section{BACKGROUND}

Breast cancer has become one of the most common cancers in women all over the world. Tumours in the breast have long been classified according to their morphologic features, histologic type and grade (severity). Identification of molecular markers such as expression of the oestrogen (ER) and progesterone receptors (PR) and the Human epidermal growth factor receptor 2 (HER-2) has offered additional predictive value for the therapeutic assessment of women diagnosed with breast cancer.1-4 More recently, gene expression analysis using DNA microarray technology has identified additional breast tumour subtypes that were not apparent using traditional histopathologic methods.

'Financial or Other Competing Interest': None.

Submission 05-06-2018, Peer Review 11-07-2018,

Acceptance 17-07-2018, Published 23-07-2018.

Corresponding Author:

Smitha G. Raj,

Assistant Professor,

Government T. D. Medical College Hospital,

Alappuzha, Kerala, India.

E-mail: achusnith605@gmail.com

DOI: $10.14260 /$ jemds $/ 2018 / 770$

\section{(c) $($ ) $\$$}

Based on gene expression profiles, breast cancer can be classified into 5 main groups. ${ }^{5-8}$

- Luminal A.

- Luminal B.

- $\quad$ Basal-like or Triple-negative.

- Human epidermal growth factor receptor 2 .

- $\quad$ Normal breast-like.6-9

Triple-negative cancer occurs only if there is no expression of Oestrogen Receptor (ER), Progesterone Receptor (PR) and there is neither expression nor amplification of Human epidermal growth factor receptor 2 in a tumour.10,11 Basal-like tumours originate in the outer ("basal") cells that line the mammary ducts. Their incidence has been estimated to be between $13 \%$ and $25 \%{ }^{12-13}$ of all breast cancer subtypes around the world 14,15 and $10 \%-17 \%$ in western countries. ${ }^{16}$ Triple-negative disease is diagnosed more frequently in younger and premenopausal women ${ }^{17-20}$ and is highly prevalent in African-American women reporting upto $30 \% .^{21-23,24-25}$ They are often aggressive $26-28$ and are associated with a prognosis poorer than those for the luminal A, luminal B and normal breast-like types. ${ }^{27}$ Metastatically, they seem to disseminate to the axillary nodes and less frequently to bone. 
Triple-negative cancer has attracted more attention, both clinically and experimentally because of its high-risk biological characteristics and lacking of effective treatment method. Patients with triple-negative cancer do not benefit from hormonal or targeted-based therapies because of the loss of target receptors such as ER, PR and HER-2. Hence, surgery chemotherapy and radiotherapy, individually or in combination appear to be the only available modalities. Triple-negative cancers are reported to respond to neoadjuvant chemotherapy, $, 929,30$ but overall survival in patients with such tumours is still poor and management of these patients may require more aggressive treatment.

The human epidermal growth factor receptor 2 tumours are named for their status as HER2+. They tend to be ER-, PRand lymph node-positive with poorer grades. They may contain p53 mutations. The HER2+ have relatively poor prognoses and are prone to early and frequent relapse and to distant metastasis. ${ }^{27,31}$ The normal breast-like tumours are those that do not fall into any of the other categories. They account for $6 \%-10 \%$ of all breast cancers. These tumours are usually small and typically have a good prognosis. ${ }^{32}$ They are more common in post-menopausal than in pre-menopausal women.

\section{Objectives}

To compare and analyse the clinico-pathological features, recurrence, metastasis and prognosis of patients with triplenegative breast cancer and non-triple-negative female breast cancer.

\section{MATERIALS AND METHODS}

Study Design- A retrospective descriptive study.

\section{Study Setting}

Department of Radiotherapy, TDMC, Alappuzha.

Study Period- January $1^{\text {st }}$ to December 31st 2011.

\section{Sample Size}

200 patients ( 100 patients from each arm).

All patients with tissue biopsy proved carcinoma breast registered to the Department of Radiotherapy at TD Medical College Hospital, Alappuzha would be taken into this study. The ER, PR and HER2/ErbB2 receptor in the tumour cell of these patients were assessed in the Department of Pathology in this Hospital. The patients were categorised as triplenegative if they are negative for ER, PR and HER2/ErbB2 (Cut-off of less than $1 \%$ positive tumour cells). The human epidermal growth factor receptor 2 is assessed by means of IHC or FISH. Immunohistochemistry is scored on a qualitative scale from 0 to $3+$ based on interpretation of membranous staining intensity where 0 and $1+$ is classified as negative, $2+$ as borderline and $3+$ as positive. HER2 $(++)$ tissues are reevaluated by FISH analysis and if the HER2 gene amplification copy-to-CEP17 ratio greater than 2.0 was accepted as HER2 positive. Tumour's pathological diagnosis are according to the WHO histological classification of breast tumour grade according to the modified Patley-Scarff scoring system and clinical stage according to the TNM criteria (Tumour-nodemetastasis).

\section{Inclusion Criteria}

1. All histologically proven stage IIIA carcinoma breastAny size tumour with-

- Metastases in ipsilateral axillary lymph nodes fixed of matted (N2a) or

- Metastases, only in clinically apparent ipsilateral mammary nodes without clinically evident axillary lymph nodes (N2b).

2. Patients of age above 30 years and below 65 years.

3. Female sex.

4. Those with Karnofsky performance status $>60 \%$.

5. Those with adequate haematopoietic, hepatic, cardiac and kidney function.

\section{Data Collection Procedure}

Between January $1^{\text {st }} 2011$ and December 31st 2011, a total of 200 stage III female breast cancer patients (100 triplenegative patients and 100 non-triple-negative patients) confirmed by surgery and pathological examination are taken for this study. These patients were treated with surgery, chemotherapy and radiation based on recommendation of the National Comprehensive Cancer Network Guidelines. Human epidermal growth factor receptor 2 positive patients were managed with trastuzumab or lapatinib and hormone receptor-positive patients were managed with hormone receptor-targeted therapies such as tamoxifen or aromatase inhibitors. The patient's clinicopathological data and necessary investigations will be collected from case records in our department. Patient's follow-up were done once in two months initially, then the duration were increased to once in four months and then once in six months by regular clinical examination and necessary investigations in our outpatient department. Separate proforma will be filled for each patient and all those patients who fulfil the inclusion criteria will be categorised into their ER/ PR/ HER2 status. Relevant characteristics of these two groups for the last five years will be compared.

During follow-up patients might have recurrence or metastasis or death. Among these patients, probabilities of death from this cancer and other causes in the presence of competing risks (patients may have developed diabetic, renal, cardiac and neurological diseases during that period) were optimal measures of prognosis.

\section{Statistical Method}

All statistical calculations were performed using the SPSS 17.0 statistical software. Data analysis was done by using Pearson's Chi-square test. To compare the demographics and tumour characteristics between the patients with triplenegative breast cancer and non-triple negative breast cancer using a $\chi^{2}$-test for frequencies. For all analyses, $p$-values were two-sided and considered to be statistically significant if $\mathrm{p}$ values were $<0.05$.

\section{Disease Free Interval}

Is calculated in months by using the subject's date of completion of Chemotherapy and/ or Radiotherapy and one of the following: (a) Clinical evidence of Loco-regional recurrence and (b) Clinical and/ or Radiological evidence of systemic recurrence of breast cancer. 


\section{Local Recurrence}

Is defined as the recurrence occurring in the affected side of breast or regional lymph node.

\section{Distant Metastasis}

Is defined as the clinical or radiographic examination showing as distant spread.

\section{Disease Free Survival (DFS)}

It was defined as the time from diagnosis of breast cancer to first loco-regional or distant recurrence.

\section{Overall Survival (OS)}

It was the time from breast cancer diagnosis to death.

\section{RESULTS}

\begin{tabular}{|c|c|c|c|c|c|c|}
\hline Characteristics & & TNBC $(n=100)$ & Non-TNBC $(n=100)$ & $\chi^{2}$ & df & $\mathbf{p}$ \\
\hline \multirow{2}{*}{ Age } & $<35$ & 12 & 6 & \multirow{2}{*}{2.198} & \multirow[t]{2}{*}{1} & \multirow{2}{*}{0.138} \\
\hline & $\geq 35$ & 88 & 94 & & & \\
\hline \multirow{2}{*}{ Menopausal status } & No & 46 & 48 & \multirow{2}{*}{0.080} & \multirow[t]{2}{*}{1} & \multirow{2}{*}{0.777} \\
\hline & Yes & 54 & 52 & & & \\
\hline \multirow{2}{*}{ Family history } & Yes & 27 & 13 & \multirow{2}{*}{6.125} & \multirow[t]{2}{*}{1} & \multirow{2}{*}{0.013} \\
\hline & No & 73 & 87 & & & \\
\hline \multirow{2}{*}{ Tumour size } & $<5 \mathrm{~cm}$ & 47 & 69 & \multirow{2}{*}{9.934} & \multirow[t]{2}{*}{1} & \multirow{2}{*}{0.002} \\
\hline & $\geq 5 \mathrm{~cm}$ & 53 & 31 & & & \\
\hline \multirow{2}{*}{ Lymphatic invasion } & Yes & 65 & 48 & \multirow{2}{*}{5.879} & \multirow[t]{2}{*}{1} & \multirow{2}{*}{0.015} \\
\hline & No & 35 & 52 & & & \\
\hline \multirow{2}{*}{ Histologic grade } & III & 21 & 20 & \multirow{2}{*}{0.031} & \multirow[t]{2}{*}{1} & \multirow{2}{*}{0.861} \\
\hline & II & 79 & 80 & & & \\
\hline \multirow{2}{*}{ Clinical stage } & IIIA $\mathrm{T}_{2} \mathrm{~N}_{2} \mathrm{M}_{0}$ & 28 & 22 & \multirow{2}{*}{0.960} & \multirow[t]{2}{*}{1} & \multirow{2}{*}{0.327} \\
\hline & IIIA $\mathrm{T}_{3} \mathrm{~N}_{2} \mathrm{M}_{0}$ & 72 & 88 & & & \\
\hline & ble 1. The cor & son of Clinicop & cal Features betweet & wo Gr & & \\
\hline
\end{tabular}

N- Number of Patients.

This research showed that $46 \%$ of the patients with triple-negative cancer were premenopausal women, the triple-negative patients with age $<35$ years old were more than the non-triple-negative cancer. ${ }^{33,34}$ In this study histological grade of triplenegative cancer was similar with non-triple-negative cancer, but the rate of the people who had the family history of breast cancer, the rate of lymphatic invasion and larger tumour size (more than 5 centimetres) in triple-negative cancer was higher than that of in non-triple-negative cancer that was statistically significant. ${ }^{34}$

\begin{tabular}{|c|c|c|c|c|c|c|}
\hline \multirow[t]{2}{*}{$\begin{array}{c}\text { Local Recurrence or Distant } \\
\text { Metastasis }\end{array}$} & \multicolumn{2}{|c|}{$\begin{array}{l}\text { Triple-Negative } \\
\text { Breast Cancer }\end{array}$} & \multicolumn{2}{|c|}{$\begin{array}{l}\text { Non-Triple-Negative } \\
\text { Breast Cancer }\end{array}$} & \multirow[t]{2}{*}{$\chi^{2}$} & \multirow[t]{2}{*}{$\mathbf{P}$} \\
\hline & Case & $\%$ & Case & $\%$ & & \\
\hline Local recurrence & 10 & 10 & 4 & 4 & 2.765 & 0.096 \\
\hline Distant metastasis & 14 & 14 & 9 & 9 & 1.228 & 0.268 \\
\hline Metastatic Site & \multicolumn{2}{|c|}{$\mathrm{N}=14$} & \multicolumn{2}{|c|}{$\mathrm{N}=9$} & & \\
\hline Lungs & 6 & 43 & 4 & 44 & 0.006 & 0.940 \\
\hline Bones & 1 & 7 & 1 & 11 & 0.109 & 0.742 \\
\hline Liver & 2 & 14 & 2 & 22 & 0.240 & 0.624 \\
\hline Brain & 5 & 36 & 2 & 22 & 0.471 & 0.493 \\
\hline Death in recurrence & 8 & 80 & 2 & 50 & 2.718 & 0.099 \\
\hline Death in metastasis & 12 & 86 & 5 & 70 & 2.584 & 0.108 \\
\hline
\end{tabular}

N- Number of Patients.

The incidence of local recurrence and metastases to organs and death in the triple-negative patients was much higher than that in the non-triple-negative cancer patients during the first 5 years after diagnosis. The rate of visceral organs metastases was higher than the rate of bone metastases. The rate of lung and brain metastases in triple-negative group were all higher than those in the non- triple-negative group, but differed not significantly.

\begin{tabular}{|c|c|c|c|c|c|c|c|c|c|}
\hline \multirow{2}{*}{\multicolumn{2}{|c|}{ Characteristics }} & \multicolumn{3}{|c|}{ Triple-Negative Breast Cancer } & \multicolumn{3}{|c|}{ Non-Triple-Negative Breast Cancer } & \multirow{3}{*}{$\chi^{2}$} & \multirow{2}{*}{$\mathbf{p}$} \\
\hline & & Case & $\mathbf{N}$ & $\%$ & Case & $\mathbf{N}$ & $\%$ & & \\
\hline & & 100 & 24 & 24 & 100 & 13 & 13 & & \\
\hline \multirow{2}{*}{ Age } & $<35$ & 12 & 4 & 33.3 & 6 & 1 & 16.7 & 0.554 & 0.457 \\
\hline & $\geq 35$ & 88 & 20 & 22.7 & 94 & 12 & 12.8 & 3.112 & 0.078 \\
\hline \multirow{2}{*}{$\begin{array}{c}\text { Menopausal } \\
\text { status }\end{array}$} & No & 46 & 14 & 30.4 & 48 & 3 & 6.3 & 9.274 & 0.002 \\
\hline & Yes & 54 & 10 & 18.5 & 52 & 10 & 19.2 & 0.009 & 0.925 \\
\hline \multirow{2}{*}{ Family history } & Yes & 13 & 6 & 46.2 & 27 & 5 & 18.5 & 3.361 & 0.067 \\
\hline & No & 87 & 18 & 20.7 & 73 & 8 & 11 & 2.762 & 0.097 \\
\hline \multirow{2}{*}{ Tumour size } & $<5 \mathrm{~cm}$ & 47 & 17 & 36.2 & 69 & 11 & 15.9 & 6.247 & 0.012 \\
\hline & $\geq 5 \mathrm{~cm}$ & 53 & 7 & 13.2 & 31 & 2 & 6.5 & 0.933 & 0.334 \\
\hline
\end{tabular}




\begin{tabular}{|c|c|c|c|c|c|c|c|c|c|}
\hline \multirow{2}{*}{$\begin{array}{c}\text { Lymphatic } \\
\text { invasion }\end{array}$} & Yes & 65 & 22 & 33.8 & 48 & 13 & 27.1 & 0.591 & 0.442 \\
\cline { 2 - 10 } & No & 35 & 2 & 5.7 & 52 & 0 & & 3.041 & 0.081 \\
\hline \multirow{2}{*}{\begin{tabular}{c} 
Histologic grade \\
\cline { 2 - 10 }
\end{tabular}} & III & 21 & 16 & 76.2 & 20 & 12 & 60 & 1.240 & 0.265 \\
\hline \multirow{2}{*}{ Clinical stage } & II & 79 & 8 & 10.1 & 80 & 1 & 1.3 & 5.865 & 0.015 \\
\cline { 2 - 10 } & ${\text { III T } \mathrm{T}_{2} \mathrm{~N}_{2} \mathrm{M}_{0}}_{2} \mathrm{I}_{0}$ & 28 & 11 & 39.3 & 22 & 6 & 27.3 & 0.792 & 0.373 \\
& IIIA T2 & 13 & 18.1 & 78 & 7 & 9 & 2.672 & 0.102 \\
\hline
\end{tabular}

$\mathrm{N}$ - Number of patients and \%- percentage of patients with local recurrence and metastasis.

During the 5-years period of observation, in 24 patients there occurred recurrence and metastasis in triple-negative group and 13 patients in the non-triple-negative group. In this study, local relapse and metastases occurred earlier in triple-negative patients. In this study those patients with the family history of breast cancer, premenopausal women, larger tumour size (more than 5 centimetres), higher clinical stage, high grade and lymphatic invasion had higher rate of local recurrence and metastasis in triplenegative group than that in the non-triple-negative group that was statistically significant.

\begin{tabular}{|c|c|c|c|c|c|c|c|c|c|}
\hline \multirow{2}{*}{\multicolumn{2}{|c|}{$\begin{array}{c}\text { DFS } \\
\text { Characteristics }\end{array}$}} & \multicolumn{3}{|c|}{$\begin{array}{l}\text { Triple-Negative } \\
\text { Breast Cancer }\end{array}$} & \multicolumn{3}{|c|}{$\begin{array}{c}\text { Non-Triple-Negative } \\
\text { Breast Cancer }\end{array}$} & \multirow[t]{3}{*}{$\chi^{2}$} & \multirow[t]{3}{*}{$\mathbf{p}$} \\
\hline & & \multirow{2}{*}{$\begin{array}{c}\text { Case } \\
100\end{array}$} & \multirow{2}{*}{$\begin{array}{c}\mathbf{N} \\
76\end{array}$} & \multirow{2}{*}{$\begin{array}{l}\% \\
76\end{array}$} & \multirow{2}{*}{$\begin{array}{c}\text { Case } \\
100\end{array}$} & \multirow{2}{*}{$\begin{array}{c}\mathbf{N} \\
87\end{array}$} & \multirow{2}{*}{$\begin{array}{l}\% \\
87 \\
\end{array}$} & & \\
\hline & & & & & & & & & \\
\hline \multirow{2}{*}{ Age } & $<35$ & 12 & 6 & 50 & 6 & 4 & 66.7 & 0.450 & 0.502 \\
\hline & $\geq 35$ & 88 & 70 & 79.5 & 94 & 83 & 88.3 & 2.599 & 0.107 \\
\hline \multirow{2}{*}{ Menopausal status } & No & 46 & 35 & 76.1 & 48 & 42 & 87.5 & 2.065 & 0.151 \\
\hline & Yes & 54 & 41 & 75.9 & 52 & 45 & 86.5 & 1.949 & 0.163 \\
\hline \multirow{2}{*}{ Family history } & Yes & 13 & 4 & 30.8 & 27 & 23 & 85.2 & 11.844 & 0.001 \\
\hline & No & 87 & 72 & 82.8 & 73 & 64 & 87.7 & 0.751 & 0.386 \\
\hline \multirow{2}{*}{ Tumour size } & $<5 \mathrm{~cm}$ & 47 & 31 & 66 & 69 & 60 & 87 & 7.292 & 0.007 \\
\hline & $\geq 5 \mathrm{~cm}$ & 53 & 45 & 84.9 & 31 & 27 & 87.1 & 0.077 & 0.782 \\
\hline \multirow{2}{*}{$\begin{array}{l}\text { Lymphatic } \\
\text { invasion }\end{array}$} & Yes & 65 & 46 & 70.8 & 48 & 40 & 83.3 & 2.397 & 0.122 \\
\hline & No & 35 & 30 & 85.7 & 52 & 47 & 90.4 & 0.449 & 0.503 \\
\hline \multirow[b]{2}{*}{ Histologic grade } & III & 21 & 9 & 42.9 & 20 & 14 & 70 & 3.064 & 0.080 \\
\hline & II & 79 & 67 & 84.8 & 80 & 73 & 91.3 & 1.567 & 0.211 \\
\hline \multirow{2}{*}{ Clinical stage } & III A $\mathrm{T}_{2} \mathrm{~N}_{2} \mathrm{M}_{0}$ & 28 & 22 & 78.6 & 22 & 19 & 86.4 & 0.507 & 0.477 \\
\hline & IIIA $\mathrm{T}_{3} \mathrm{~N}_{2} \mathrm{M}_{0}$ & 72 & 54 & 75 & 78 & 68 & 87.2 & 3.658 & 0.056 \\
\hline
\end{tabular}

$\mathrm{N}$ - Number of patients and \%- percentage of patients with 5 years Disease-Free Survival.

The 5-years Disease-Free Survival in difference characteristics of each groups were studied. The Disease-Free Survival was lower in triple-negative group than those in non-triple-negative group. During the 5 years' period of observation, patients with the family history of breast cancer and small tumour size (less than 5 centimetres), the 5 years Disease-Free Survival was more in nontriple-negative patients than in triple-negative patients that was statistically significant.

\begin{tabular}{|c|c|c|c|c|c|c|c|c|c|}
\hline \multirow{2}{*}{\multicolumn{2}{|c|}{ Characteristics }} & \multirow{2}{*}{\multicolumn{3}{|c|}{$\begin{array}{c}\text { Triple-Negative } \\
\text { Breast Cancer }\end{array}$}} & \multirow{2}{*}{\multicolumn{3}{|c|}{$\begin{array}{c}\text { Non-Triple-Negative Breast } \\
\text { Cancer }\end{array}$}} & \multirow[t]{4}{*}{$\chi^{2}$} & \multirow[t]{4}{*}{$\mathbf{p}$} \\
\hline & & & & & & & & & \\
\hline & & \multirow{2}{*}{$\begin{array}{c}\text { Case } \\
100\end{array}$} & \multirow{2}{*}{$\begin{array}{c}\mathbf{N} \\
80\end{array}$} & \multirow{2}{*}{$\begin{array}{l}\% \\
80\end{array}$} & \multirow{2}{*}{$\begin{array}{c}\text { Case } \\
100\end{array}$} & \multirow{2}{*}{$\begin{array}{c}\mathbf{N} \\
93\end{array}$} & \multirow{2}{*}{$\begin{array}{l}\mathbf{\%} \\
93 \\
\end{array}$} & & \\
\hline & & & & & & & & & \\
\hline \multirow{2}{*}{ Age } & $<35$ & 12 & 6 & 50 & 6 & 5 & 83.3 & 1.870 & 0.171 \\
\hline & $\geq 35$ & 88 & 74 & 84.1 & 94 & 88 & 93.6 & 4.217 & 0.04 \\
\hline \multirow{2}{*}{ Menopausal status } & No & 46 & 37 & 80.4 & 48 & 44 & 91.7 & 2.487 & 0.115 \\
\hline & Yes & 54 & 43 & 79.6 & 52 & 49 & 94.2 & 4.927 & 0.026 \\
\hline \multirow{2}{*}{ Family history } & Yes & 13 & 5 & 38.5 & 27 & 23 & 85.2 & 9.122 & 0.003 \\
\hline & No & 87 & 75 & 86.2 & 73 & 70 & 95.9 & 4.381 & 0.036 \\
\hline \multirow{2}{*}{ Tumour size } & $<5 \mathrm{~cm}$ & 47 & 34 & 72.3 & 69 & 64 & 92.8 & 8.886 & 0.003 \\
\hline & $\geq 5 \mathrm{~cm}$ & 53 & 46 & 86.8 & 31 & 29 & 93.5 & 0.933 & 0.334 \\
\hline \multirow{2}{*}{ Lymphatic invasion } & Yes & 65 & 49 & 75.4 & 48 & 42 & 87.5 & 2.585 & 0.108 \\
\hline & No & 35 & 31 & 88.6 & 52 & 51 & 98.1 & 3.489 & 0.062 \\
\hline \multirow{2}{*}{ Histologic grade } & III & 21 & 12 & 57.1 & 20 & 15 & 75 & 1.453 & 0.228 \\
\hline & II & 79 & 68 & 86.1 & 80 & 78 & 97.5 & 6.910 & 0.009 \\
\hline \multirow{2}{*}{ Clinical stage } & IIIA $\mathrm{T}_{2} \mathrm{~N}_{2} \mathrm{M}_{0}$ & 28 & 23 & 82.1 & 22 & 20 & 90.9 & 0.786 & 0.375 \\
\hline & IIIA $\mathrm{T}_{3} \mathrm{~N}_{2} \mathrm{M}_{0}$ & 72 & 13 & 79.2 & 78 & 73 & 93.6 & 6.740 & 0.009 \\
\hline & & & & Gro & & & & & \\
\hline
\end{tabular}

$\mathrm{N}$ - Number of patients and \%- Percentage of patients with 5 years overall survival. 
During the 5 years period of observation, overall survival was lower in triple-negative group than those in non-triplenegative group. Patients with older age, post-menopausal women, family history, small tumour size (less than $5 \mathrm{~cm}$ ), higher histologic grade and stage, the 5 years overall survival, more in non-triple-negative patients than in triple-negative patients that was statistically significant.

\section{DISCUSSION}

Triple-negative breast cancer was a distinct subgroup of breast cancer with particular clinico-pathologic behaviour. Compared with the non-triple-cancer, triple-negative breast cancer was characterised by larger tumour size, more positive axillary lymph node, higher clinical stage and higher histological grade, higher tendency for metastasis and lower disease-free survival and overall survival rate which were consistent with previous reports.16,33-34 These characters played the important roles in judging the prognosis of triplenegative breast cancer patients.

In this study age less than 35 years old patients were more in triple-negative than the non-triple-negative groups, which were consistent with previous reports. Some studies reported that the triple-negative group had the higher rate of the family history of breast cancer than the rate in non-triplenegative group. In this study the rate of the people who had the family history of breast cancer in triple-negative group was statistically significant, higher than that in the nontriple-negative group. The result suggested that triplenegative cancer patients have the familial inheritance tendency.

Dent et al ${ }^{18}$ conducted a long-term follow-up of 1608 breast cancer patients and found that the incidence of metastases to visceral organs in the triple-negative patients was much higher than that in the non-triple-negative patients during the first 5 years after diagnosis. Lin et al ${ }^{35}$ analysed the sites of distant recurrence in 116 metastatic triplenegative patients and reported that the majority of metastases were in lungs and liver. The brain was the third most common site of recurrence. Rakha et al reported that in a study of 1944 breast cancer patients, local relapse and metastases occurred earlier in triple-negative patients. The rate of visceral organs metastases was higher than the rate of bone metastases. According to our study the lungs, liver and brain were the first three most common sites of metastases and the rate of local relapse and the rate of metastases in these sites, more in triple-negative patients than that in the non-triple-negative patients which all differed not significantly.

Bauer et al and other reports ${ }^{36}$ showed that clinical stage and histological grade are significantly related to the prognosis of triple-negative cancer, the higher pathological stage and grade of the tumour, the lower the disease-free survival and overall survival of the patient. In our study nontriple-negative patients with tumour size less than 5 centimetres without lymphatic invasion and any histological grade were found to have more disease-free survival and patients with small tumour size (less than 5 centimetres) had statistically significant 5 years disease-free survival. Patients with older age, post-menopausal women, family history, small tumour size (less than 5 centimetres), higher histologic grade and stage, the 5 years overall survival more in non- triple-negative patients than in triple-negative patients that was statistically significant.

Triple-negative cancer which are resistant to the existing ER, PR and HER2-targeted therapies, sequential chemotherapies remain. It is the only routine treatment option. The microtubule-targeting agent Eribulin improved survival in a randomised trial including patients with triplenegative cancer who received at least two prior lines of chemotherapy.37-38 Addition of platinum agents to anthracycline/ taxane neoadjuvant chemotherapy demonstrated statistically significant higher pathological complete response rates $(41 \%$ vs. $54 \%$; $37 \%$ vs. $53 \% ; 26 \%$ vs. $51 \%$ ). ${ }^{39-41}$ The adjuvant trial of olaparib (Poly ADP-ribose polymerase inhibitors) should be considered for high-risk germline BRCA-mutant early-stage triple-negative cancer. The diversity and rarity of potentially targetable mutations in triple-negative cancer slow the progress of developing biologically targeted therapies for this disease. ${ }^{42}$ There are many ongoing clinical trials and investigations of the role of immune checkpoint inhibitors, the mTOR inhibitor everolimus and a pan-phosphoinositide 3-kinase PI3K inhibitor, antibody-drug conjugates and other immunetargeted agents in breast cancer. ${ }^{43,44}$

\section{CONCLUSION}

In this study, it was found that reason for the poor prognosis of triple-negative breast cancer patients were special biological characteristics such as younger age, higher rate of breast cancer, family history, bigger tumour size, more advanced clinical stage upon diagnosis, higher rate of lymph node metastasis, higher histological grade, earlier recurrence and metastasis and non-susceptibility to endocrine and targeted therapy. In cases where the cancer is caught in earlier stages and treated effectively, a person has a much higher survival rate than if it is discovered in the later stages, where the cancer has spread or does not respond to treatment. Besides standard surgical and radiation therapy, other treatment modalities to check the mutations at different levels should be developed.

\section{REFERENCES}

[1] Early Breast Cancer Trialists' Collaborative Group (EBCTCG). Effects of chemotherapy and hormonal therapy for early breast cancer on recurrence and 15year survival: an overview of the randomized trials. Lancet 2005;365(9472):1687-717.

[2] Kamangar F, Dores GM, Anderson WF. Patterns of cancer incidence, mortality and prevalence across five continents: defining priorities to reduce cancer disparities in different geographic regions of the world. J Clin Oncol 2006;24(14):2137-50.

[3] Konecny G, Pauletti G, Pegram M, et al. Quantitative association between HER-2/neu and steroid hormone receptors in hormone receptor-positive primary breast cancer. J Natl Cancer Inst 2003;95(2):142-53.

[4] Slamon DJ, Godolphin W, Jones LA, et al. Studies of the HER-2/neu proto-oncogene in human breast and ovarian cancer. Science 1989;244(4905):707-12.

[5] Brenton JD, Carey LA, Ahmed AA, et al. Molecular classification and molecular forecasting of breast cancer: ready for clinical application? J Clin Oncol 2005;23(29):7350-60. 
[6] Perou CM, Sørlie T, Eisen MB, et al. Molecular portraits of human breast tumours. Nature 2000;406(6797):747-52.

[7] Reis-Filho JS, Westbury C, Pierga JY. The impact of expression profiling on prognostic and predictive testing in breast cancer. J Clin Pathol 2006;59(3):22531.

[8] Sørlie T, Perou CM, Tibshirani R, et al. Gene expression patterns of breast carcinomas distinguish tumor subclasses with clinical implications. Proc Natl Acad Sci U S A 2001;98(19):10869-74.

[9] Rouzier R, Perou CM, Symmans WF, et al. Breast cancer molecular subtypes respond differently to preoperative chemotherapy. Clin Cancer Res 2005;11(16):5678-85.

[10] Hammond ME, Hayes DF, Dowsett M, et al. American Society of Clinical Oncology/College of American Pathologists guideline recommendations for immunohistochemical testing of estrogen and progesterone receptors in breast cancer. J Clin Oncol 2010;28(16):2784-95.

[11] Goldhirsch A, Wood WC, Coates AS, et al. Strategies for subtypes-dealing with the diversity of breast cancer: highlights of the St. Gallen International Expert Consensus on the Primary Therapy of Early Breast Cancer 2011. Ann Oncol 2011;22(8):1736-47.

[12] Dairkee SH, Ljung BM, Smith $H$, et al. Immunolocalization of a human basal epithelium specific keratin in benign and malignant breast disease. Breast Cancer Res Treat 1987;10(1):11-20.

[13] Gusterson B. Do "basal-like" breast cancers really exist? Nat Rev Cancer 2009;9(2):128-34.

[14] Nielsen TO, Hsu FD, Jensen $K$, et al. Immunohistochemical and clinical characterization of the basal-like subtype of invasive breast carcinoma. J Clin Cancer Res 2004;10(16):5367-74.

[15] Banerjee S, Reis-Filho JS, Ashley S, et al. Basal-like breast carcinomas: clinical outcome and response to chemotherapy. J Clin Pathol 2006;59(7):729-35.

[16] Rakha EA, EI-Sayed ME, Green AR, et al. Prognostic markers in triple-negative breast cancer. Cancer 2007;109(1):25-32.

[17] Carey LA, Perou CM, Livasy CA, et al. Race, breast cancer subtypes and survival in the Carolina Breast Cancer Study. JAMA 2006;295(21):2492-502.

[18] Dent R, Trudeau M, Pritchard KI, et al. Triple-negative breast cancer: clinical features and patterns of recurrence. Clin Cancer Res 2007;13(15 Pt 1):442934.

[19] Haffty BG, Yang Q, Reiss M, et al. Locoregional relapse and distant metastasis in conservatively managed triple negative early-stage breast cancer. J Clin Oncol 2006;24(36):5652-7.

[20] Tischkowitz M, Brunet JS, Bégin LR, et al. Use of immunohistochemical markers can refine prognosis in triple negative breast cancer. BMC Cancer 2007;7:134.

[21] Trivers KF, Lund MJ, Porter PL, et al. The epidemiology of triple-negative breast cancer, including race. Cancer Causes Control 2009;20(7):1071-82.
[22] Dolle JM, Daling JR, White E, et al. Risk factors for triple-negative breast cancer in women under the age of 45 years. Cancer Epidemiol Biomarkers Prev 2009;18(4):1157-66.

[23] Huo D, Ikpatt F, Khramtsov A, et al. Population differences in breast cancer: survey in indigenous African women reveals over-representation of triplenegative breast cancer. J Clin Oncol 2009;27(27):4515-21.

[24] Bauer KR, Brown M, Cress RD, et al. Descriptive analysis of estrogen receptor (ER)-negative, progesterone receptor (PR)-negative, and HER2negative invasive breast cancer, the so-called triplenegative phenotype: a population-based study from the California Cancer Registry. Cancer 2007;109(9):1721-8.

[25] Morris GJ, Naidu S, Topham AK, et al. Differences in breast carcinoma characteristics in newly diagnosed African-American and Caucasian patients: a singleinstitution compilation compared with the National Cancer Institute's Surveillance, Epidemiology and End Results database. Cancer 2007;110(4):876-84.

[26] Rakha EA, Reis-Filho JS, Ellis IO. Basal-like breast cancer: a critical review. J Clin Oncol 2008;26(15):2568-81.

[27] Abd El-Rehim DM, Pinder SE, Paish CE, et al. Expression of luminal and basal cytokeratins in human breast carcinoma. J Pathol 2004;203(2):661-71.

[28] Fan C, Oh DS, Wessels L, et al. Concordance among gene-expression-based predictors for breast cancer. $\mathrm{N}$ Engl J Med 2006;355(6):560-9.

[29] Cleator S, Heller W, Coombes RC. Triple-negative breast cancer: therapeutic options. Lancet Oncol 2007;8(3):235-44.

[30] Carey LA, Dees EC, Sawyer L, et al. The triple negative paradox: primary tumor chemosensitivity of breast cancer subtypes. Clin Cancer Res 2007;13(8):2329-34.

[31] Fulford LG, Reis-Filho JS, Ryder K, et al. Basal-like grade III invasive ductal carcinoma of the breast: patterns of metastasis and long-term survival. Breast Cancer Res 2007;9(1):R4.

[32] Calza S, Hall P, Auer G, et al. Intrinsic molecular signature of breast cancer in a population-based cohort of 412 patients. Breast Cancer Res 2006;8(4):R34.

[33] Yuan ZY, Wang SS, Gao Y, et al. Clinical characteristics and prognosis of triple-negative breast cancer: a report of 305 cases. Ai Zheng: Chin J Cancer 2008;27(6):561-5.

[34] Yang DH, Liu H, Zhao J. Clinicopathologic features and prognosis of triple negative breast cancer. Chinese Clinical Oncology 2008;35:501-4.

[35] Lin NU, Claus E, Sohl J, et al. Sites of distant recurrence and clinical outcomes in patients with metastatic triple-negative breast cancer: high incidence of central nervous system metastases. Cancer 2008;113(10):2638-45.

[36] Zhang L, Hao C, Dong G, et al. Analysis of clinical features and outcome of 356 triple-negative breast cancer patients in China. Breast Care (Basel) 2012;7(1):13-7. 
[37] Skeel RT, Khleif SN. Hand book of cancer chemotherapy. $8^{\text {th }}$ edn. Philadelphia, PA: Lippincott Williams \& Wilkins 2011.

[38] Grann VR, Troxel AB, Zojwalla NJ, et al. Hormone receptor status and survival in a population-based cohort of patients with breast carcinoma. Cancer 2005;103(11):2241-51.

[39] Sikov WM, Berry DA, Perou CM, et al. Impact of the addition of carboplatin and/or bevacizumab to neoadjuvant once-per-week paclitaxel followed by dose-dense doxorubicin and cyclophosphamide on pathologic complete response rates in stage II to III triple-negative breast cancer: CALGB 40603 (Alliance). J Clin Oncol 2015;33(1):13-21.

[40] Rugo HS, Olopade OI, DeMichele A, et al. Adaptive randomization of veliparib-carboplatin treatment in breast cancer. N Engl J Med 2016;375(1):23-34.
[41] Von Minckwitz G, Schneeweiss A, et al. Neoadjuvant carboplatin in patients with triple-negative and HER2positive early breast cancer (GeparSixto; GBG 66): a randomised phase 2 trial. Lancet Oncol 2014;15(7):747-56.

[42] Santarpia L, Bottai G, Kelly CM, et al. Deciphering and targeting oncogenic mutations and pathways in breast cancer. Oncologist 2016;21(9):1063-78.

[43] Miron A, Varadi M, Carrasco D, et al. PIK3CA mutations in in situ and invasive breast carcinomas. Cancer Res 2010;70(14):5674-8.

[44] Shah SP, Roth A, Goya R, et al. The clonal and mutational evolution spectrum of primary triplenegative breast cancers. Nature 2012;486(7403): 395-9. 